\title{
A model for facilitation in nursing education
}

\author{
E Lekalakala-Mokgele, PhD. (Nursing) \\ School of Nursing, University of the Free State \\ PP du Rand, PhD. (Nursing) \\ School of Nursing, University of the Free State
}

\section{Keywords:}

Community perceptions, quality, (primary) health care, Limpopo Province, South Africa

\section{Correspondence address:}

Dr. E. Lekalakala-Mokgele

School of Nursing

University of the Free State

P.O Box 339

Bloemfontein

9300

$\mathrm{Tel} / \mathrm{Fax}(051)$ 40I-2407

E-mail: gnvkem.MD@mail.uovs.ac.za

\section{Abstract: Curationis 28(2): 22-29}

A key step in the development of a model for learning is to identify the needs of both the facilitators and the learners. The purpose of this study was to develop a model for facilitation in nursing education based on the identified needs of facilitators and learners and a confirmation by the literature. A qualitative research design was used and the population of the study was the facilitators and the learners of departments/ schools of nursing in four universities in South Africa. Focus group interviews were conducted with facilitators and learners. The sample was purposively selected. The results underline the needs as well as the perceptions of both facilitators and learners with regard to facilitation. Concepts were identified and analyzed from the identified needs which led to the development of the model for facilitation. The complete visual model was described and presented to experts for evaluation. Feedback from the evaluators was used to adapt and finalize the model, after which the model was again presented to evaluators who approved and accepted it. The model is a unique contribution to nursing education as it sets guidelines for a new field of learning in nursing education.

\section{Abstrak}

In hierdie navorsing was dit belangrik om die behoeftes van studente en fasiliteerders te bepaal ten einde " $n$ model vir fasilitering in verpleegonderrig te ontwikkel. Die doelstelling was dus om 'n model van fasilitering in vepleegonderrig daar te stel. Die model is gebaseer op die behoeftes van studente en fasiliteerders ten opsigte van fasilitering sowel as ' $n$ uitgebreide literatuur ondersoek oor fasilitering. Die navorsing was kwalitatief van aard en die populasie van die studie was die fasiliteerders en leerders van departemente of skole van verpleegkunde aan universiteite in Suid Afrika. Fokusgroep onderhoude met leerders en fasiliteerders is gehou. Die steekproef was doelgerig. Resultate het duidelik die behoeftes en probleme van die leerders en fasilieteerders aangedui. Konsepte was geïdentifiseer en geanaliseer van die behoeftes/ probleme van die leerders en fasiliteerders en het aanleiding gegee tot die ontwikkeling van die model. Die visuele model is beskryf en aan kundiges vir die nodige evaluering voorgelê. Nadat veranderinge soos deur die paneel voorgestel aangebring is, is die model weer na kundiges uitgestuur wat dit goedgekeur en aanvaar het. Hierdie model is " $n$ unieke bydrae tot verpleegonderrig omrede dit riglyne stel vir " $n$ nuwe veld in verpleegonderrig.

\section{Introduction}

Higher education in general is under both internal and external pressure to change and this transformation has also put nursing education in the spotlight of change (Republic of South Africa, 1995:5). Evidence of this change is the transfer of hospital-based to communitybased education and the introduction of non-traditional methods such as problem-based learning (PBL), community-based education (CBE) as well as inquiry-based learning (IBL). These methods emphasize that effective 


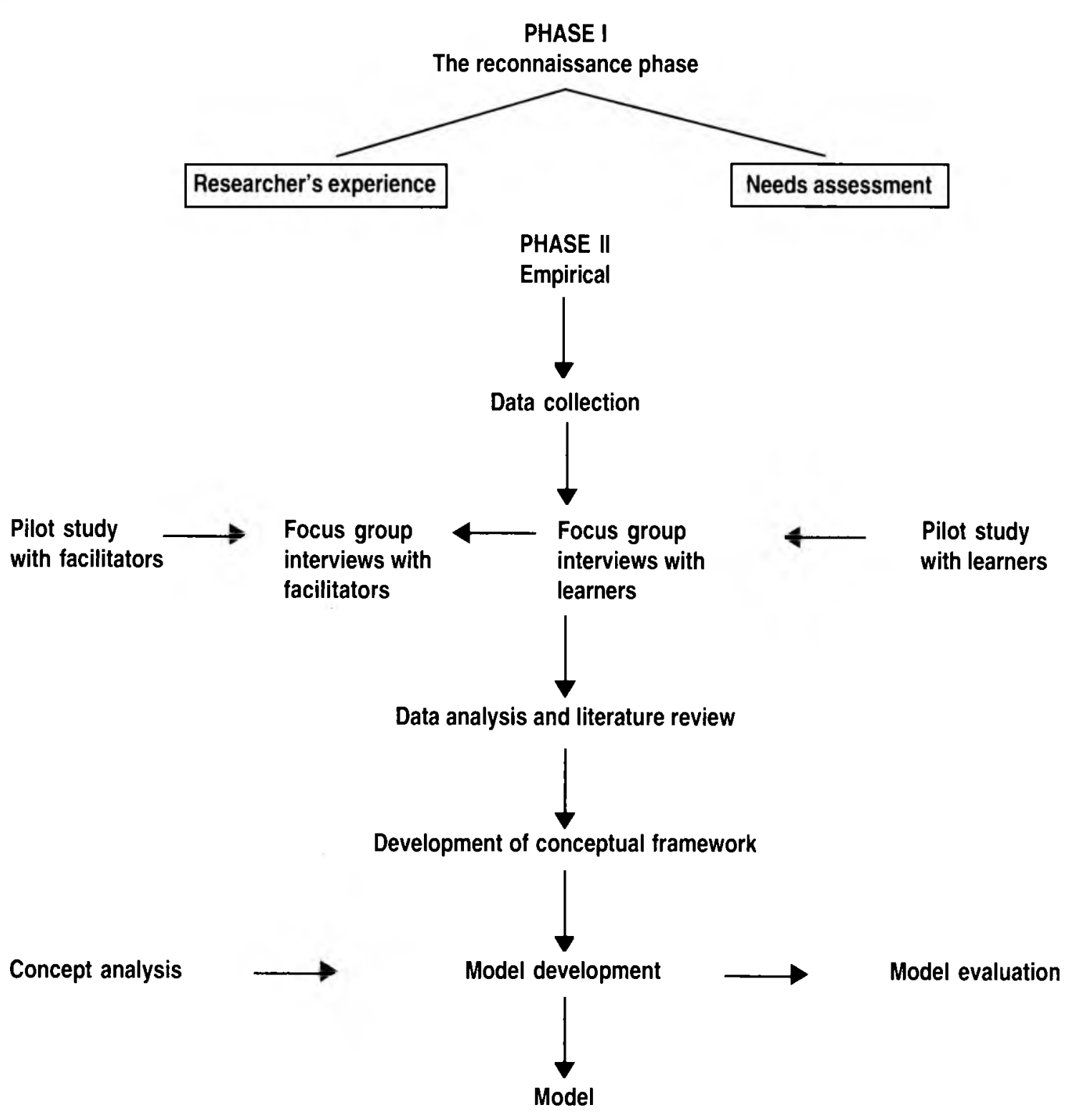

learning cannot be limited to the delivery of information but that the active participation of the learner is essential.

The starting point would be the revision of the traditional teaching role of the lecturer which, according to Creedy and Hand (1994: 696-702) is characterized by the dominance and control of learning by the teacher. Changing this role to that of a facilitator of learning means that the facilitator licenses the students to assume control and direct their own learning (Andrews \& Jones, 1996:357365). Effective learning is possible when the role of the teacher is not that of a controller and provider of information but that of a facilitator and manager of the learning process (Erasmus \& van Dyk, 1996:67). This necessitates the development of a model for facilitation because in the past lecturers were trained to lecture and not to facilitate learning.

\section{Problem statement}

The study evolves from the introduction of a non-traditional teaching/learning method, problem-based learning (PBL) and the move from curative care to community-based learning (CBE) in the undergraduate programme of the School of Nursing of the University of the Free State (UFS). The planning of the curriculum for PBL and CBE in the School of Nursing of the University of the Free State was extensive. The focus was on the process of PBL and $\mathrm{CBE}$ and not much on facilitation. All lecturers were trained to lecture and not to facilitate learning. Lecturers attended several workshops and conferences, locally and internationally, but this seemed to be inadequate in preparing facilitators for their new role. This was confirmed by research conducted by Fichardt and Du Rand (2000:3-10) on assessing the perceptions of facilitators of problembased learning and community-based education in the School of Nursing of the Free State University. There was no role model or expert who could demonstrate good facilitation. Most of the facilitation was learned by trial and error. Facilitators struggled to adapt to this mode of teaching because there were no guidelines for facilitation.

The students who register for the undergraduate nursing course come from school backgrounds where self-directed learning until recently has not been encouraged (Becker, 1999:4). The students were unfamiliar with learning by using facilitation, they struggled to adapt 
to this mode of learning and their needs regarding the method were not known. It was therefore important to make an assessment of both the facilitator and learners needs in order to develop a model to meet those needs.

\section{Aim of the study}

The aim of the study was to develop a model for the process of facilitation in nursing education

\section{Objectives}

- To identify the needs of the facilitators in different schools of nursing.

- To identify the needs of the students with regard to facilitation.

- To construct a model for facilitation according to the determined needs.

\section{Reseach design}

In this explorative and descriptive study a qualitative design was used and the research was contextual in nature. The combined methods of theory generation of Chinn and Kramer (1999) and Duldt and Giffin (1985) as well as the steps of Lancaster and Lancaster (1992) for building a model were used for designing the model.

\section{Sample}

The sample was purposively selected and included the facilitators and learners in the schools and departments of nursing of four South African universities using facilitation as a teaching-learning method and who were willing to take part in the research. A total of 12 focus groups were conducted. Two (one with facilitators and the others with learners) of the twelve were pilot studies to test the research question and to practise the technique. The data of the pilot study was not included in the study. Of the ten (10), four focus groups were held with facilitators and six (6) with students. At each university one focus group was held with the facilitators. Regarding the students, two focus groups each were conducted in two universities and one focus group each was held with the remaining two universities

\section{Ethical considerations}

Informed consent was sought prior to conducting the focus group discussions.
All participants were assured that confidentiality and anonymity would be maintained. Participants were informed that participation was voluntary and they had the right to discontinue their participation if they felt uncomfortable or did not wish to continue. Informants agreed to be part of focus group discussions and none of them left before discussions were completed

\section{Data collection}

The research technique used were focus group interviews or discussions. The outcome of this study is not the generalization of results because of its explorative nature, but a deeper understanding of experiences from the perspectives of both facilitators and learners (Maykut \& Morehouse, 1994:44). Only one open-ended question was asked to enable the facilitators and the learners to share personal thoughts, perceptions and feelings in an unstructured manner.

The question was "How do you experience facilitation as a teaching/ learning method?. An expert in the facilitation of focus groups was approached to act as focus group facilitator or moderator in different sessions.

\section{Field notes}

The researcher took field notes. Moloto (1999:57) states that the tasks of the researcher are to develop questions, facilitate the sessions, document data during the session, analyze the data and interpret the results.

\section{Data analysis}

Data was analyzed by means of a combination of Tesch (1990) in Cresswell (1994:153-155) who described eight steps of analyzing data and the basic steps of Giorgi (1970) as quoted by Omery (1983:49-63). The researcher read through all the transcripts and thoughts were written in margins. Similar concepts were clustered together.

Data was then read for the second time comparing it to the list of concepts identified to form categories. Data belonging to the same category was assembled. Redundant information was identified and eliminated.

Data was integrated and synthesized into descriptive structure of the experiences of facilitators and the learners.

The final product was submitted to the co-coder for analysis.

\section{Literature control}

Literature control was carried out to examine and verify trends and similarities in the data obtained. The results of the analyzed data from the transcribed material of the focus group discussions were used to identify, classify and categorize important themes and statements concerning the study.

\section{Validity and reliability}

Trustworthiness was maintained by using strategies of credibility, transferabilty, dependability and conformability (Lincoln \& Guba, 1985:290-327). Credibility was achieved by cross-examination of data and literature control.

Dependability was ensured by dense description of data and the use of the cocoder. Presenting the model to different evaluators whose input can be used by facilitators to improve their facilitation skills ensured transferability.

Being close to respondents when conducting focus group interviews ensured conformability.

\section{Phases of model development}

The model was developed according to the diagrammatic representation in Figure 1. The model was designed in two phases, namely the reconnaissance or scouting and the empirical phases (see Figure 1).

The reconnaissance phase describes the experiences of the researcher as well as the study conducted to assess the needs and challenges of the facilitators in the School of Nursing of the University of the Free State. Data was collected in Phase 2.

A pilot study was conducted with a group of facilitators and learners in which facilitation as a teaching and learning method was used to test the research question. After the pilot study, focus group interviews with the facilitators and the learners were held and data was analysed with literature control. The framework of the model evolved from the experiences of the researcher, the needs assessment as well as the available data supported by the literature.

A model was developed from the data of the focus group interviews.

Concepts were defined which led to the development of the model. The model was presented to evaluators for acceptance. 


\section{A model for facilitation in nursing education}

The combined methods of theory generation of Chinn and Kramer (1999) and Duldt and Giffin (1985) as well as the steps of Lancaster and Lancaster (1992) for building the model were used for designing the model

\section{The purpose of the model}

The model has four purposes:

The main purpose is that learning must take place through the process of facilitation.

- $\quad$ The model should give guidelines to prepare facilitators for their new role of facilitation.

- It is also designed to enable facilitators of learning to make the learners the focus of the learning event.

- $\quad$ The model will assist facilitators to understand their roles in the learning process during facilitation and to understand the learners.

\section{Constructivism}

It is the philosophy of constructivism to view knowledge as something that the learners must construct by themselves through their interaction with the environment (Chalmers \& Fuller, 1996:18; Duffy \& Cunningham, undated: 171 ; von Glaserfeld, 1995:3-16). Constructivism builds on the knowledge known by the learner (Dougiamas, 1998). This model is based on the philosophy of constructivism.

\section{Assumptions}

The model is based on a number of assumptions, some of which have been taken from the paradigm guiding the research and some of which have been derived from the identified concepts. The main assumptions are from adult learning theory. Other assumptions relevant to this model, namely those from symbolic interaction theory (Pearson, Vaughan \& Fitzgerald, 1997:45) are included.

\section{Definition of concepts in the model}

Copi's (1968:115-118) principles for defining concepts were applied in defining the concepts in the model The following concepts together create a model for facilitation in nursing education.

\section{Facilitation}

Facilitation is the central concept in this model. It is both a method and a strategy for learning (Brockbank and McGill (1998:145) Salmon (1980:5) Holtzhausen (1998:33-37) Rooth (1995:95). As a central concept facilitation takes place in the classroom and in the clinical setting in a small group format according to the data collected from both facilitators and learners. It is based on the principles of adult learning and it requires the involvement of both the learners and their facilitator through the process of interaction. Real-life situations are the basis and these encourage life-long learning as learning is contextual. Facilitation promotes critical thinking in the learners and both become reflective learners. Their problem-solving ability as well as their clinical reasoning is developed.

\section{Learning}

Learning focuses on the process of discovery in which the learner seeks to understand issues and the issues that guide the discovery process must be personally relevant (Duffy \& Cunningham, undated ) According to constructivism learning is contextual and should occur or be situated in a realistic setting. It also occurs within a social context (Dalgarno: On line) and is culturally constructed (Boud and Felleti, 1993:7-8). Learning should lead to the cognitive, affective and psychomotor development of the learner.

\section{Adult learning}

Nursing learners are regarded as adults (Klopper, 1999:2) The reason is that most consumers of nursing care are adults (Nunnery, 1997:199) and nurses are expected to be more responsible for the lives of people. Adult learning is characterized by the following principles:

- $\quad$ An adult self-concept includes being treated as being capable of self-direction.

- Adults need to recognize the purpose of learning

- $\quad$ They will build on their own life experience

- $\quad$ Adults will learn best if the learning is task-, problem- or inquiry-centred.

- $\quad$ Adults will learn when they are ready.
They are motivated to learn by growth, accomplishment, curiosity and self-esteem (Majundar, 1996:43-46).

\section{Facilitator}

The facilitator is the person responsible for helping the learners to construct knowledge. According to the data the facilitator must posses the following qualities:

$\begin{array}{ll}\text { - } & \text { Self-awareness } \\ \text { - } & \text { Be approachable } \\ \text { - } & \text { Senpathetic } \\ \text { - } & \text { Non-dominant } \\ \text { Patient and acceptable to the } \\ \text { learner }\end{array}$

The multiple roles that the facilitator must perform include the following:

\section{- $\quad$ Provide structure for learning \\ - Guide the learners \\ - Identify learning resources \\ - Create a climate conducive to learning \\ - $\quad$ Encourage cultural competence by exposing the learners to clients in diverse settings \\ - Motivate learners \\ - Support them in the theoretical and clinical settings \\ - Act as a role model and sometimes even in a parental role}

Facilitation requires that the facilitator have certain skills and these are:

$\begin{array}{ll}\text { - } & \text { Communication } \\ \text { - } & \text { Tolerance of silence } \\ \text { - } & \text { Puestioning skills } \\ \text { - } & \text { Guiding } \\ \text { - } & \text { Conflict management } \\ \text { - } & \text { Leadership, and being able to } \\ & \text { Begotiate } \\ \end{array}$

\section{Learner}

Nursing learners are regarded as adults (Klopper, 1999:2). ). This is because most consumers of nursing care are adults (Nunnery, 1997:199) and nurses are expected to be more responsible for the lives of people. Learners must acquire three main components, namely nursing knowledge, nursing competencies and professional values. 
Core competencies expected to be learned through facilitation include:

$\begin{array}{ll}\text { - } & \text { Critical thinking } \\ \text { - } & \text { Communication } \\ \text { - } & \text { Problem solving } \\ \text { - } & \text { Clinical competency } \\ \text { - } & \text { Geflective learning } \\ \text { - } & \text { Affective skills }\end{array}$

Professional values include factors such as:

- Autonomy, which is the ability to function independently while autonomy of learning is a capacity for lifelong learning (Health Science and Social service Document Pack, 2002:27).

- Advocacy for clients and the nursing profession, to ensure that no harm is done to the patient.

- $\quad$ Ethics which deal with the moral aspects of nursing and these should be facilitated both in the classroom and the clinical setting.

- $\quad$ Role model: the learner should be a role model for the nursing profession and represent nursing by her or his good conduct.

- $\quad$ Accountability: The learner is accountable to patients and the nursing profession.

Another aspect the learner should develop is nursing knowledge. This is the knowledge that the learner as a nurse has constructed based on personal experience. Nursing knowledge includes the following:

- Health care which is the scientific knowledge gained to care for clients

- Health promotion and disease prevention

- $\quad$ Skills to undertake research

- Technology to assist in the diagnosis and management of disease

- $\quad$ Health education to prevent disease and promote health

\section{Classroom setting}

Facilitation in the classroom occurs in small groups. These groups provide expertise from the rest of the group which is not available to the solitary individual (Gregory \& Thornley, 1994:20). The group members plan activities together as well as reflect on how their activities could be more effective. The size of the group should be between four and fifteen members, it should be small enough to encourage diversity of viewpoints and ideas and not too large so that it interferes with face-to-face interactions. Members receive feedback from one another to improve group activities. They also manage the group by setting ground rules and by agreeing to commitment through a learning contract (Dana, 1997:41-43). All group activities are assessed.

\section{Clinical setting}

Facilitation also occurs in the clinical setting. The literature describes the clinical setting as more than just a place to apply theory to practice. It is where the learner learns problem-solving, decision-making and divergent thinking skills necessary for dealing with the uncertainties of clinical practice. (Reilly and Oermann 1985, in Dana \& Gwele, 1998:58-64, Mashaba 1994:44, Chabeli (1998:39-44). The clinical setting may be the hospital, clinic, patient's home or an old age home.

\section{Assessment}

Ladyshewsky (1991:24) describes assessment as an essential and necessary component of professional competency measurement. It is imperative that the process of facilitation be assessed. From the data and the literature the following are concluded about assessment in facilitation:

\section{Relationship statements of the model}

According to Breakwell, Hammond and Fife-Schaw (1998:7) theories are basically sets of relational rules. They contain many concepts and specify how concepts relate to one another (Neuman, 1997:43). Chinn and Kramer (1991:116) suggest that concepts should be given a structural form so as to clarify their relationship by means of a symbolic representation.

Based on the definitions provided in the preceding section, the following relationships are proposed:

- Facilitation takes place in the context of nursing education.
The focus of nursing education is the learner, the facilitator, the process of facilitation, as well as the learning environment, which may be the classroom or the clinical setting.

- Learning takes place through the process of facilitation.

- Facilitation is based on the philosophy of constructivism and the principles of adult learning are applied.

- $\quad$ The principles of adult learning indicate that certain aspects of learning need to be taken into consideration when dealing with adult learners, for example facilitation requires understanding of how learners experience learning otherwise the purpose of facilitation may be defeated.

- Learning is facilitated when learners participate in the learning process.

- $\quad$ The main role players in learning through facilitation are the facilitator and the adult learners.

- The facilitator must have skills, certain qualities, develop a relationship, with the learners and have roles to fulfil in helping the learners to develop core competencies, the nursing role and professional values.

- The facilitator interacts with the learners in facilitation through the process of dialogue, negotiation and discourse.

- $\quad$ The learners interact with the learning environment by being active participants in the learning process.

In facilitation learning takes place in the classroom through group work and in the clinical setting.

- $\quad$ The goal of facilitated learning in nursing education is to produce a competent theoretical nurse at the same time as a practical nurse is produced because nursing is a practice-based profession; hence facilitation occurs in the classroom and the clinical setting.

- $\quad$ The relationship between the facilitator and the learner and between the learners is a much more complex interaction and process than in the traditional 
form of teaching.

- The facilitator supports the learners by means of scaffolding and mentoring.

- It is important for the process of facilitation to be assessed

- The group members assess one another as well as the facilitator, and then they all assess the facilitation process and the group dynamics

- $\quad$ First each learner should reflect on his or her own work and interactions with the group. Second, each learner should reflect on the contributions of other members, considering both their methods and efforts. Finally, members should share their thoughts about how the group operated as a whole.

It should be a formalized structure of schools.

- Different strategies should be used such as designing standardized assessment tools Assessment should be carried out frequently, for example at the end of every session or completion of a module.

- $\quad$ Peer assessment should be encouraged and learners should select the criteria and carry out the assessment (du Toit, Khabanjane, Korf, Kotze, Masehela, Mostert, van Tonder, 2000:59).

- Formative and summative assessment should be used.

\section{Evaluation of the model}

A tentative model was constructed and sent to 10 evaluators to be evaluated. Overall feedback indicates that the model was accepted but that some changes were needed to be implemented for a final model. The researcher adapted the model as valuable input was received from the evaluators

\section{Conclusion}

The data collected indicates that the facilitators as well as the learners experienced problems with facilitation as a teaching/learning method. The data and the literature review guided the researcher in developing the model. The main purpose of the model is that learning must take place through the process of facilitation and that it should give guidelines to the facilitators as well as the learners. Facilitation was the central concept in the model. Other important role players are the learner and the facilitator. The research indicated the need for the development of a model.

\section{Acceptability and usability of the model}

This model provides nursing educators with aspects that must be considered in training nurse educators to become facilitators. The traditional training methods must include facilitation as a teaching-learning method. Models are not intended as rigid structures that must at all times be adhered to (Pearson, Vaughan \& Fitzgerald, 1997:70). This model may be used in the early stage of facilitation to provide structure or a framework to give learners direction. As facilitators' expertise develops the model may be used as a guideline or aidememoiré.

\section{Recommendations for facilitators}

- Facilitators should be thoroughly prepared for their facilitation role and should commit themselves to a paradigm shift of relinquishing classroom control and adapt to a student-centred approach.

- They should use appropriate skills to encourage learning.

- They must have facilitative personalities characterized by, for example, openness, warmth, patience and flexibility to enable learning to take place.

\section{Recommendations for}

\section{learners}

- Students should be given sufficient orientation to outline their work pattern throughout the year

- $\quad$ Students should be given support in the classroom and the clinical setting to deal with the frustrations of adapting to facilitation

\section{Recommendations for further research}

- Further research is needed on the role and function of the facilitator

\section{Recommendation for nursing education}

- $\quad$ Nurse educators should continuously revise the method of learning and shift from traditional methods of learning to self-directed learning.

- $\quad$ Nursing education should make it mandatory for the skills required of the nursing student to be built into the nursing curriculum. Development and support should be contained in the curriculum.

- $\quad$ The model as indicated in Figure 2 may be used as a guideline or aide-memoire for facilitators and learners.

\section{Summary}

The study was undertaken to construct a model for facilitation in nursing education. The needs of the facilitators and learners regarding facilitation were identified, based on their experiences of this mode of teaching and learning. A qualitative research design was used. Purposive sampling from all universities using non-traditional methods of teaching was implemented. Findings indicate that both the learners and facilitators experienced problems with facilitation. A model was constructed with the aim of providing guidelines. Recommendations are proposed for the facilitator, learner, and nursing education.

\section{Bibliography}

ANDREWS, M \& JONES, PK 1996: Problem-based learning in an undergraduate nursing programme: $A$ case study. Journal of Advanced Nursing. 23:357-365.

BECKER, S 1999: Evaluation of problem-based learning in an undergraduate nursing education programme. Bloemfontein: University of the Free State (M.Soc.Sc. in Nursing)

BOUD, D \& FELETTI, G 1991: Introduction. (In: Boud, D. \& Feletti, G. (Eds.) The challenge of problem-based learning. London: Kogan Page).

BROCKBANK, A \& McGILL, I 1998: Facilitating reflective learning in higher 


\section{MODEL FOR FACILITATION}

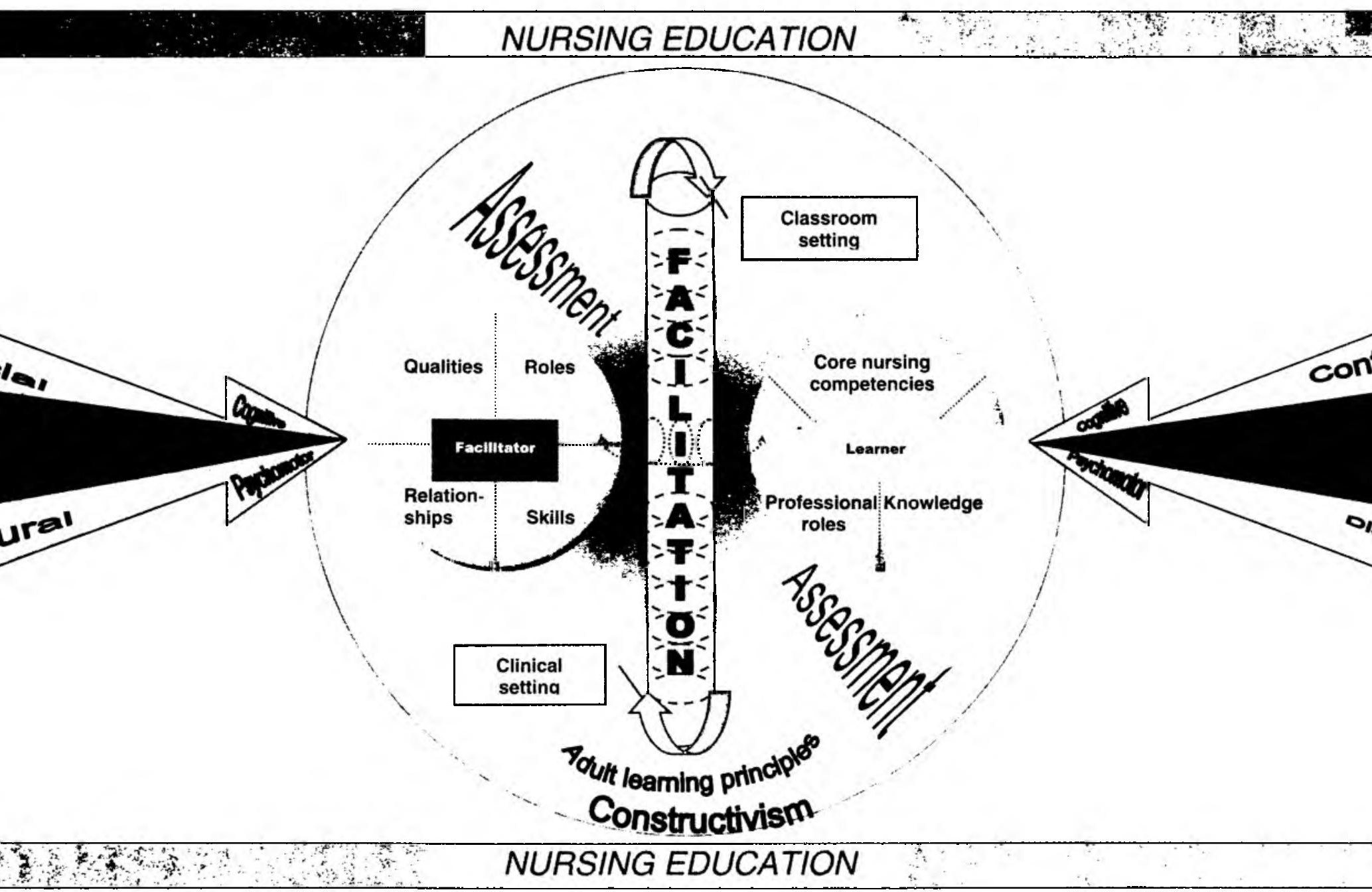


education. Philadelphia: Open University Press.

COPI, IM 1968: Introduction to logic. $3^{\text {rd }}$ ed. London: MacMillan Co.

ERASMUS, BJ \& VAN DYK, PS 1999: Training management in South Africa. $2^{\text {nd }}$ ed. Johannesburg: International Thompson Publishing (Pty.) Ltd.

BREAKWELL, GM; HAMMOND,S \& FIVE-SCHAW, C 1998: Research methods in psychology. London: Sage Publications

CHABELI, M 1998: Professional nurses as reflective clinical learning facilitators. Curationis. 21(2):39-44.

CHALMERS, D \& FULLER, R 1996: Teaching for learning at university: Theory and practice. London: Kogan Page.

CHINN, PL \& KRAMER, MK 1991: Theory and nursing: A systematic approach. $3^{\text {rd }}$ ed. St. Louis C.V. Mosby Co.

CHINN, PL \& KRAMER, MK 1999: Theory and nursing integrated knowledge development. $5^{\text {th }} \mathrm{ed}$. St. Louis: C.V. Mosby Co.

CREEDY, D \& HAND, B 1994: The implementation of problem-based learning: Changing pedagogy in nurse education. Journal of Advanced Nursing. 20(1):696-702.

CRESWELL, JW 1994: Research design. Qualitative and quantitative

DALGARNO, B Constructivist computer assisted learning: Theory and techniques. http://www.ascilite.org.au/ conference/adelaide96/papers/21.html.

DANA, H \& GWELE, NS 1998: Perceptions of student nurses of their personal and academic development during placement in the community as a

DOUGIAMAS, M 1998. A journey into constructivism. http://dougiamas.com/ writing/ constructivism. html.

DUTOTT,G; KHABANJANE,E; KORF, W; KOTZE, G; MASEHELA, K; MOSTERT, S \& VAN TONDER, F 2000: Assessment in OBE. A project sponsored by the Ministry of the Flemish
Government, Department of Education. Final report.

DUFF, TM \& CUNNINGHAM, DJ Undated. Constructivism: Implications for the design and delivery of instruction.

DULDT, BW \& GIFFIN, K 1985: Theoretical perspectives for nursing. Boston: Little, Brown \& Co.

\section{FICHARDT, AE \& DU RAND, PP 2000:}

Facilitator's perceptions of problembased learning and community-based education. Health SA Gesondheid.

GREGORY, R \& THORLEY, L 1994: Present challenges. (In: Thorley, L. \& Gregory R. (Eds.) Using group-based learning in higher education: Teaching and learning in higher education. London: Kogan Page).

HEALTH SCIENCE AND SOCIAL SERVICES DOCUMENT PACK FOR 23 ${ }^{R D}$ PLENARY MEETING 2002: February.

HOLTZHAUSEN, SW 1998: The development of facilitators and a prerequisite to the successful transformation of educational change. South African Journal of Higher Education. 12(3):33-36

KLOPPER, H 1999: Nursing education: A reflection. $2^{\text {nd }}$ ed. Lynwood Ridge: Amabhuku Publications

LADYSHEWSKY, R 1995: Clinical teaching. Gold guide no. 1. Australia: HERDSA.

LANCASTER, W \& LANCASTER, J 1992: Models and model building in nursing. (In: Nicoll, L.H. (Ed.) Perspectives of nursing theory. $2^{\text {nd }} \mathrm{ed}$. New York: J.B. Lippincott Co).

LINCOLN, Y \& GUBA, E 1985: Naturalistic enquiry. California: sage.

MAJUMDAR, B 1996: Self-directed learning in the context of a nursing curriculum: Development of a learning plan. Curationis. 19(2):43-46.

MASHABA, TG 1994: The philosophical basis of nursing education. (In: Mashaba, T.G. \& Brink, H.I. (Eds.) Nursing education. An international perspective. Kenwyn: Juta \& Co).
MAYKUT, P \& MOREHOUSE, R 1994: Beginning qualitative research. A philosophic and practical guide. London: The Falmer Press.

MOLOTO, JC 1999: A model for the reintegration of marginalized adolescents into the community to facilitate the restoration, promotion and maintenance of their mental health. Johannesburg: Rand Afrikaans

NEUMAN, WL 1997: Social research methods. Qualitative and quantitative approaches. $3^{\text {rd }}$ ed. Boston: Allyn \& Bacon.

NUNNERY, RK 199: Advancing your career: Concepts of professional nursing. Philadelphia: F.A. Davis Co.

OMERY, A 1983: Phenomenology: A method for nursing research. Advances in Nursing Science. 5(2):49-63.

ROOTH, E 1995: Life skills: A resource book for facilitators. Menzini: MacMillan

PEARSON, A; VAUGHAN, B \& FITZGERALD, M 1997: Nursing models for practice. $2^{\text {nd }}$ ed. Oxford: ButterworthHeinemann.

REPUBLIC OF SOUTH AFRICA 1995: Ways of seeing the National Qualifications Framework. Pretoria: Human sciences research Council.

SALMON, P 1980: Coming to know. London: Routledge.

VON GLASSERFELD, E 1987: Learning as a constructive activity. In: Janvier, C. (Ed.) Problems of representation in the teaching and learning of mathematics. New Jersey: Lawrence Erlbaum Associates, Inc. 